\title{
The German Radar Surveillance around the Aber Wrach during the WW II
}

\author{
Giancarlo T. Tomezzoli \\ Etno-Archaeological Observatory, Munich, Germany \\ Email: gt21949@gmx.de
}

How to cite this paper: Tomezzoli, G. T. (2017). The German Radar Surveillance around the Aber Wrach during the WW II. Archaeological Discovery, 5, 22-41. http://dx.doi.org/10.4236/ad.2017.51002

Received: November 26, 2016 Accepted: December 20, 2016 Published: December 27, 2016

Copyright (C) 2017 by author and Scientific Research Publishing Inc. This work is licensed under the Creative Commons Attribution International License (CC BY 4.0).

http://creativecommons.org/licenses/by/4.0/ cc) (i) Open Access

\begin{abstract}
In a previous article (Tomezzoli, 2016), the issue of the German radar surveillance around the Aber Wrach in Brittany has been identified. Purpose of this article is to provide replies to said issue presenting the radar bases of Keringar Vihan, Kervingam-Kerdené and Vougo-Kerizoc. If the visits on the sites permitted to determine precisely the actual preservation state of these radar bases, the memories of the witnesses have enriched this information by identifying non-evident or completely disappeared structures, adding anecdotal and historical information and confirming the recites of archival documents. It is therefore evident that this successful dual procedure should be intensified and extended to all the future studies concerning the Atlantic Wall and, in general, to all the contemporary military structures, as long as surviving primary witnesses will be available. A megalithic stone circle discovered on the site of the radar base of Kervingam-Kerdené is presented.
\end{abstract}

\section{Keywords}

German, Radar, Surveillance, Megalithic, Stonecircle, Recumbent, Aber Wrach, Atlantic Wall, Brittany, France

\section{Introduction}

The lists of the German radar bases in France of the Deutsche Atlantikwall Archiv (DAWA, 2013) and the Rapport Pinczon de Sel (Rapport Pinczon du Sel, 1947-1948; Patrimoine Region Bretagne, 2003a, b), were useful for identifying, among other, the radar bases of Keringar Vihan, Kervingam-Kerdené and Vougo-Kerizocactive during the war for the surveillance around the Aber Wrach (Tomezzoli, 2016). Moreover, said lists identify the kind of radars, i.e. mainly Freya and Würzburg models, in service at these bases. The Freya radar was developed in a variety of different models by GEMA (von Kroge, 1998). It was provided in general with an instrumentation cabin surmounted by a rectangular, flat antenna comprising an emitter operated at $2.3-2.5 \mathrm{~m}$ wavelength, a receiver and an IFF (identification friend foe) receiver. The Freya radars 
were sensitive in a range of up to $200 \mathrm{Km}$ and needed a power supply of about $20 \mathrm{Kw}$. The Würzburg radar was developed in a variety of different models by Telefunken. In the A, B, C, D versions it was provided with a $3 \mathrm{~m}$ parabolic antenna on a wheels mobile support, in the FuSE 65Riese version it was provided with an instrumentation cabin behind a $7.5 \mathrm{~m}$ parabolic antenna provided with an emitter operated at $50 \mathrm{~cm}$ wavelength and an IFF. The FuSE 65Riese was sensitive in a range up to $70 \mathrm{~km}$ with azimuth and elevation precision of about $0.2^{\circ}$ and needed a power supply of about $160 \mathrm{Kw}$. It was usual in the German radar bases to pair Freya and Würzburg radars, the first for early warning and the second for directing the fire of anti-aircraft batteries. The Freya radars were mounted on their own supports, while the Würzburg Riese was mounted on a concrete, hexagonal support $V 229$. In both the cases, the radars were protected by ground embankments or splitting wall emplacements.

German radar bases hosting Freya and Würzburg radars were the $2^{\text {nd }}$ order Monterfil

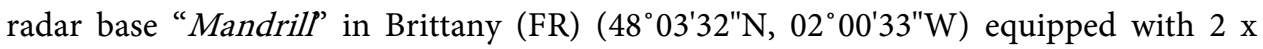
Freya-Egon with goniometer, 2 x FuSE 65 and 1 x FuSE 62D Würzburg (Dupont et al., 2007) and the $1^{\text {st }}$ order Les Mees radar base "Made" in Charente Maritime (FR) (48 19'07.72"N, 0 14'21.09"W) equipped with 2 x FuSE 80 Freya (with Gemse and A/N) and 2 x FuSE 65 (Tomezzoli \& Pottier, 2007).

\section{FuMO 451 Keringar Vihan (Re 305?)-Radar Anti-Aircraft Base}

Probably corresponding to FuMO 451 (Funk-Mess-Ortung 451-radio measuring location 451$)$ as well as to the St.P. (support point) $\operatorname{Re} 305\left(48^{\circ} 21^{\prime} 13.95^{\prime \prime} \mathrm{N}, 4^{\circ} 45^{\prime} 43.10^{\prime \prime} \mathrm{W}\right)$ (Figure 1) in the lists of the Deutsche Atlantikwall Archiv (DAWA, 2013), the Keringar Vihan early warning and Flak (anti-aircraft) base was located near the Pointe SaintMathieu, on a hill about $49 \mathrm{~m}$ height, at only $1 \mathrm{~km}$ from the heavy German M.K.B. (Marine Kuste Batterie-Navy coastal battery) Graf Spee of Keringar Wraz (Tomezzoli, 2015). It was conceived for directing the fire of its own Flak guns and, probably, also that of the Flak guns of the Graf Spee ( $\left.48^{\circ} 20^{\prime} 40.08^{\prime \prime} \mathrm{N}, 4^{\circ} 45^{\prime} 07.95^{\prime \prime} \mathrm{W}\right)$. Not mentioned by the Rapport Pinczon de Sel, the Keringar Vihan base comprised a water reservoir tank of German construction for its own water supply and that of the M.K.B Graf Spee, $2 \mathrm{x}$ Flak bunkers, 2 x Freya radar emplacements and some other bunkers of unknown type and purpose. One FuMO 2 Calais B radar is identified in service at the base (DAWA, 2013). The site visit took place on 12/09/2009.

The water reservoir tank (Figure 1, Figure 2(a)) was included in a municipal area dedicated to materials store and recycling. It was formed by a concrete tank of about 15 $\mathrm{m}$ in diameter placed on six concrete supports legs about $4 \mathrm{~m}$ height. The preservation state of its concrete structure was good without damages due to combats. Linked to conduits, it appeared still accomplishing its function of water supply. Due to its elevation and the absence of a Flak emplacement, it is possible that, during the war, it hosted on its coverage only a light machine gun emplacement and/or an observatory. A possible small bunker (2), in a cultivation field, was buried in the terrain and covered by the vegetation. Its type and purpose remained unknown. Bunker (3) (Figure 1, Figure 2 (b)) about $10 \times 5 \mathrm{~m}$ was covered by ground and emerged from the terrain for less than $1 / 2 \mathrm{~m}$. Its entrance/s was buried in the terrain, so that its interior was not accessible, 


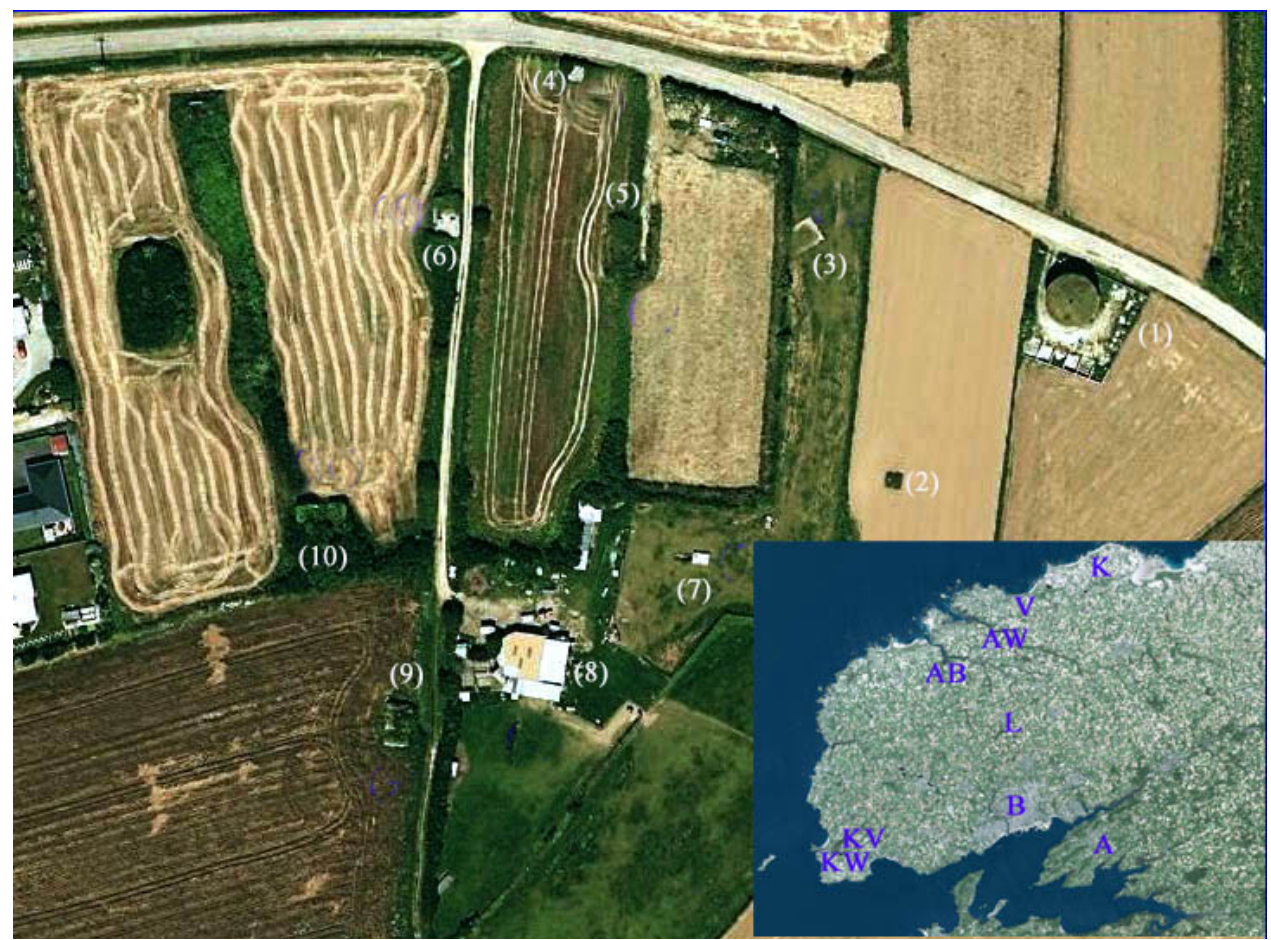

Figure 1. Keringar Vihan radar base-(1) water reservoir tank, (2) bunker of unknown type and purpose, (3) bunker of unknown type and purpose, (4) bunker of unknown type and purpose at the entrance of the base, (5) bunker of unknown type, probably either troop lodgment, or Flak fire control bunker, or a bunker type $L 406 A$ for permanent machinery like power generators, (6) Flak bunker, (7) bunker of unknown type and purpose, (8) type 1 split wall emplacement for radar Freya, (9) Flak bunker, (10) type 5 brick, split wall version for radar Freya A Armorique peninsula, AB Aber Benoît, AW Aber Wrach, B Brest, K Kervingam-Kerdené radar base; KW Keringar Wraz M. K. B Graf Spee, KV Keringar Vihan radar base, V Vougo-Kerizoc radar base, L Lesneven [Geoportail].

and its type, purpose and preservation state of its concrete structure remained undetermined. The small, square bunker (4) (Figure 1, Figure $2(\mathrm{c})$ ) about $3 \times 3 \mathrm{~m}$, at the entrance of the site, emerged less than $1 \mathrm{~m}$ from the terrain and was encircled by vegetation. Its entrance/s was not accessible, so that its type and purpose remained undetermined. The portions of its concrete structure not covered by the vegetation appeared in a good state of preservation without damages due to combats. Bunker (5) (Figure 1, Figure 2(d)) about $15 \times 10 \mathrm{~m}$ emerged less than $1 \mathrm{~m}$ from the terrain and was completely covered by vegetation. Its entrance/s was buried in the terrain, so that its interior was not accessible and its type, purpose and state of preservation of its concrete structure remained undetermined. Its dimensions suggest either a bunker type $R 621, R 622$ or $R 656$ shelters for one or two group of soldiers, or a Flak fire control bunker, or a bunker type $L 406 A$ for permanent machinery like power generators, (6) Flak bunker,. The small, rectangular bunker (7) (Figure 1, Figure 2(e)) about $4 \times 3 \mathrm{~m}$ emerged about $1 \mathrm{~m}$ from the terrain. An inclined ramp gave access to its entrance closed by a wood door, probably not of origin. The access of the interior was not possible, but its isolated position and reduced dimensions suggests a function of ammunition or depot bunker. The preservation state of its concrete structure was good without damages due to combats. No rests of a guard corps and a possible metallic barrier encircling the base re- 


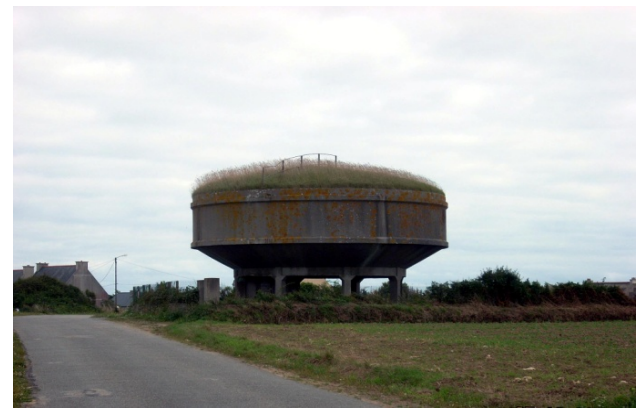

(a)

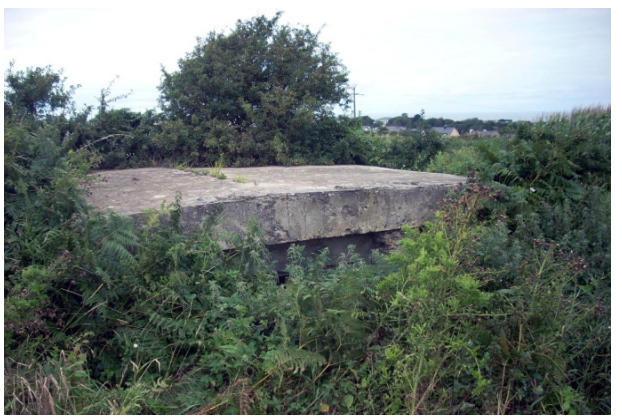

(c)

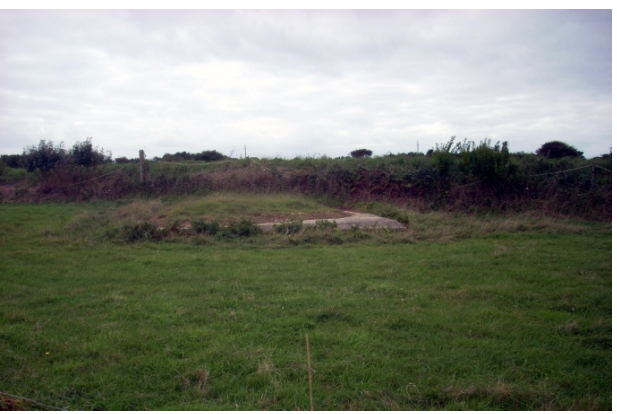

(b)

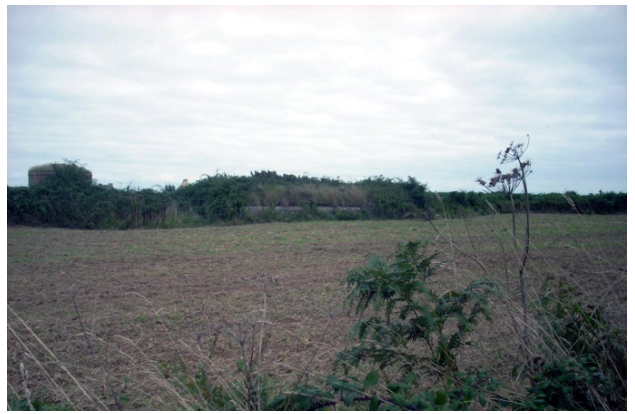

(d)

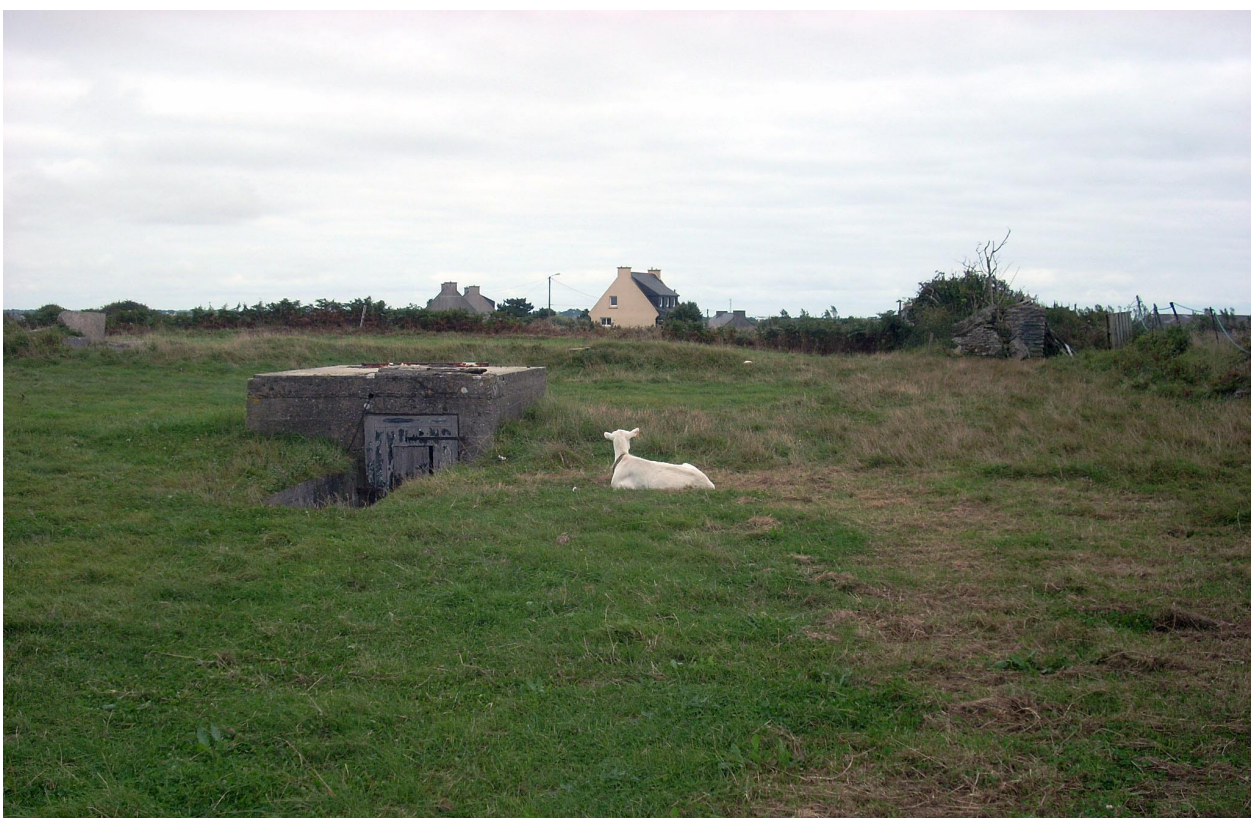

(e)

Figure 2. Keringar Vihan radar base-(a) water reservoir tank of German construction; (b) bunker (3) of unknown type covered by ground; (c) bunker (4) of unknown type at the entrance of the base; (d) bunker (5) possible shelter for a group of soldiers or Flak fire control bunker; (e) small bunker (7) possible ammunition or depot bunker.

mained visible.

Bunker (6) (Figure 1, Figure 3), located on a side of the base access road, was a Vf (Verstärkt Feldmäßigen-field reinforced) or a Sk (Sondernkonstruktion-special construction) Flak bunker. It was partially covered by vegetation which obstructed its apparently unique entrance (Figures $3(a)-(c)$ ), so that its interior was not accessible. Its 


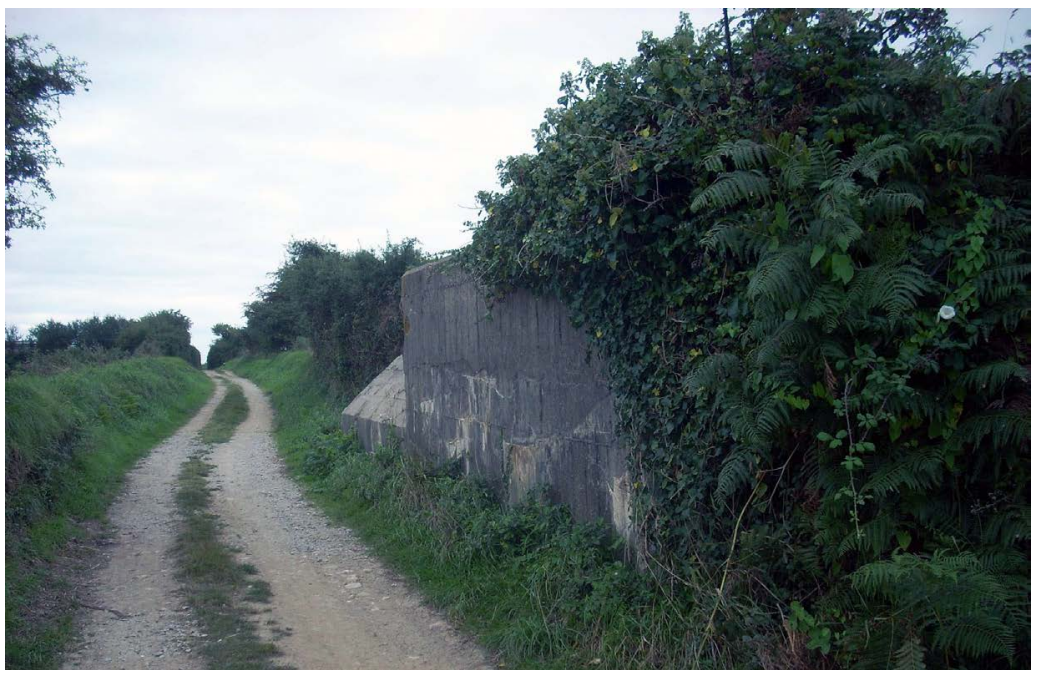

(a)

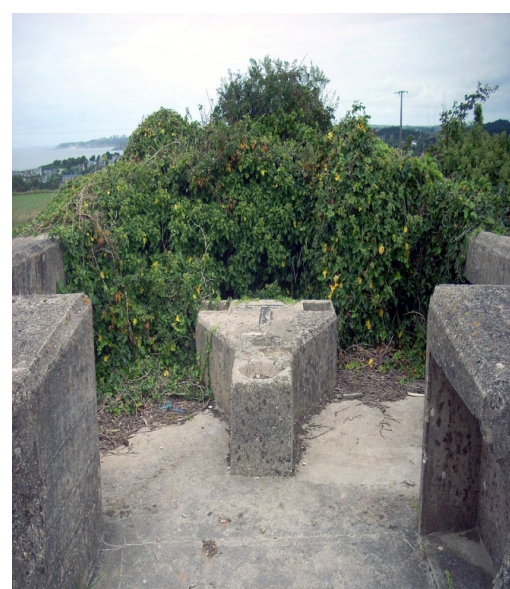

(b)

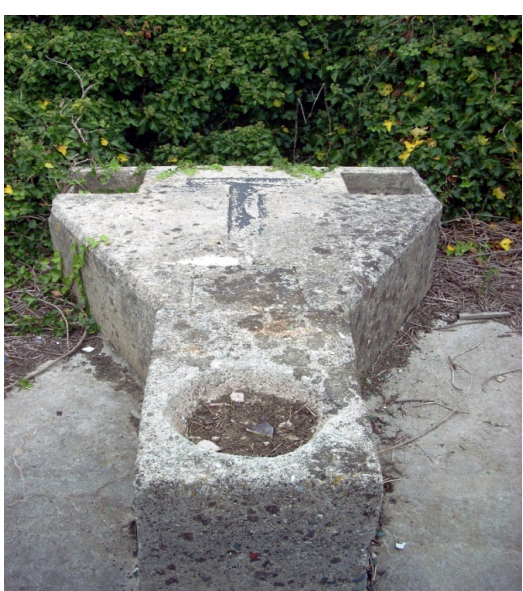

(c)

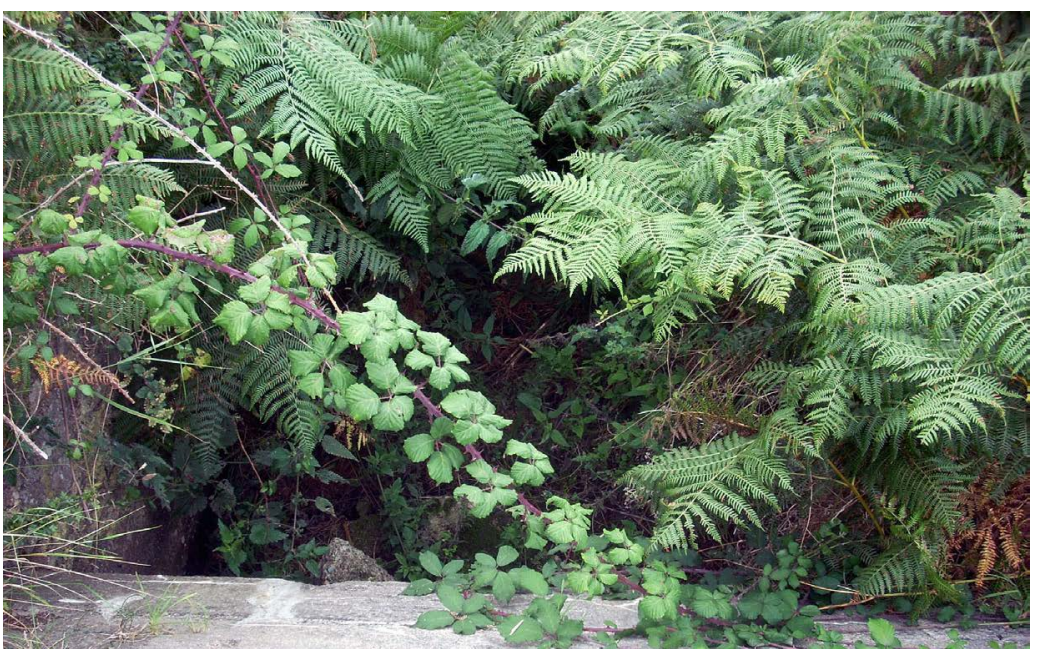

(d)

Figure 3. Keringar Vihan radar base-Vf or SkFlak bunker (6)-(a) base access road and bunker concrete structure covered by vegetation; (b) Flak gun emplacement, in the middle gun support deprived of gun support joints, on the right ammunition niche; (c) square and round cavities of the gun support; (d) vegetation obstructing the bunker entrance. 
coverage, accessible through a metallic stair above the entrance, hosted a square about $5 \times 5 \mathrm{~m}$ gun emplacement, similar to those of bunkers $L 409, L 410$, for a $37 \mathrm{~mm}$ Flak gun, with ammunition niches. The gun support presented a triangular shape with two square and one round cavities at its extremities of unknown purpose and no fixation joints for a gun support. The preservation state of the bunker concrete structure, in the portions not covered by the vegetation, was good without damages due to combats.

Bunker (9) (Figure 1, Figure 4), located at the end of the base access road, was a Vf or SkFlak bunker, twin of bunker (6). It was too partially covered by vegetation which fortunately did not obstruct its entrance (Figures 4(a)-(c)). Its coverage, accessible through the metallic stair above the entrance, hosted a square Flak gun emplacement like that of bunker (6). The triangular gun support presented three square cavities at its extremities and gun support fixation joints disposed along a circle. The visit of the interior showed that it was composed by a large, single room deprived by all the original furniture and no traces of thermal insulation. Its floor was partially invaded by water. The preservation state of the bunker concrete structure, in the portions not covered by the vegetation was substantially good, with the exception, on one side, of impact cavities (Figure 4(b)) due to projectiles of small or medium caliber gun.

The hexagonal bunker (8) (Figure 5) was a type 1 concrete, split wall emplacement for Freya radar. The owner of the site, born after the war, therefore an indirect witness, declared that at its origin the bunker was uncovered and that it hosted a radar device, but he appeared also puzzled by the news received by a relative that, during the war, the Germans had no radar. The bunker, was arranged as hen-house and workshop, and presented, in the portions not covered by the vegetation or agriculture materials, a concrete structure in a good preservation state without damages due to combats. The visit of the interior showed a well preserved concrete floor with no V229 support for FuSE 65, which confirmed that it hosted the Freya FuMO 2 Calais B radar (DAWA, 2013) mounted on its leg metallic support. On the floor, some original grooves, probably for radar cables connections, were filled with concrete by the owner after the war. The upper side of an interior wall presented impact cavities (Figure $4(\mathrm{~d})$ ) due to projectiles of small caliber machine gun. The owner declared that the nearby bunker (10) had, during the war, the same function of bunker (8), suggesting the presence, actual or foreseen, of another Freya radar at the base.

The rectangular bunker (10), about $10 \times 5 \mathrm{~m}$, was a type 5 concrete, split wall emplacement for Freya radar. Its interior, completely filled by debris and vegetation, was inaccessible and, consequently, it was not possible to ascertain whether, on the contrary, it contained a support $V 229$.

The search on the terrain for $V 229$ supports and for traces of possible disappeared wooden barracks hosting soldiers' lodgments, a canteen, kitchen and latrines gave no result. A possible estimation to about 50 the number of the personnel members in service at the base is rather uncertain.

Two split wall emplacements and only one radar identified suggest that the base was probably not completed at the retreat towards the Festung (fortress) Brest of the German troops. Two radars at the base is not surprising in order to operate one of them for surveillance during the periods in which the other was under reparation or maintenance. 


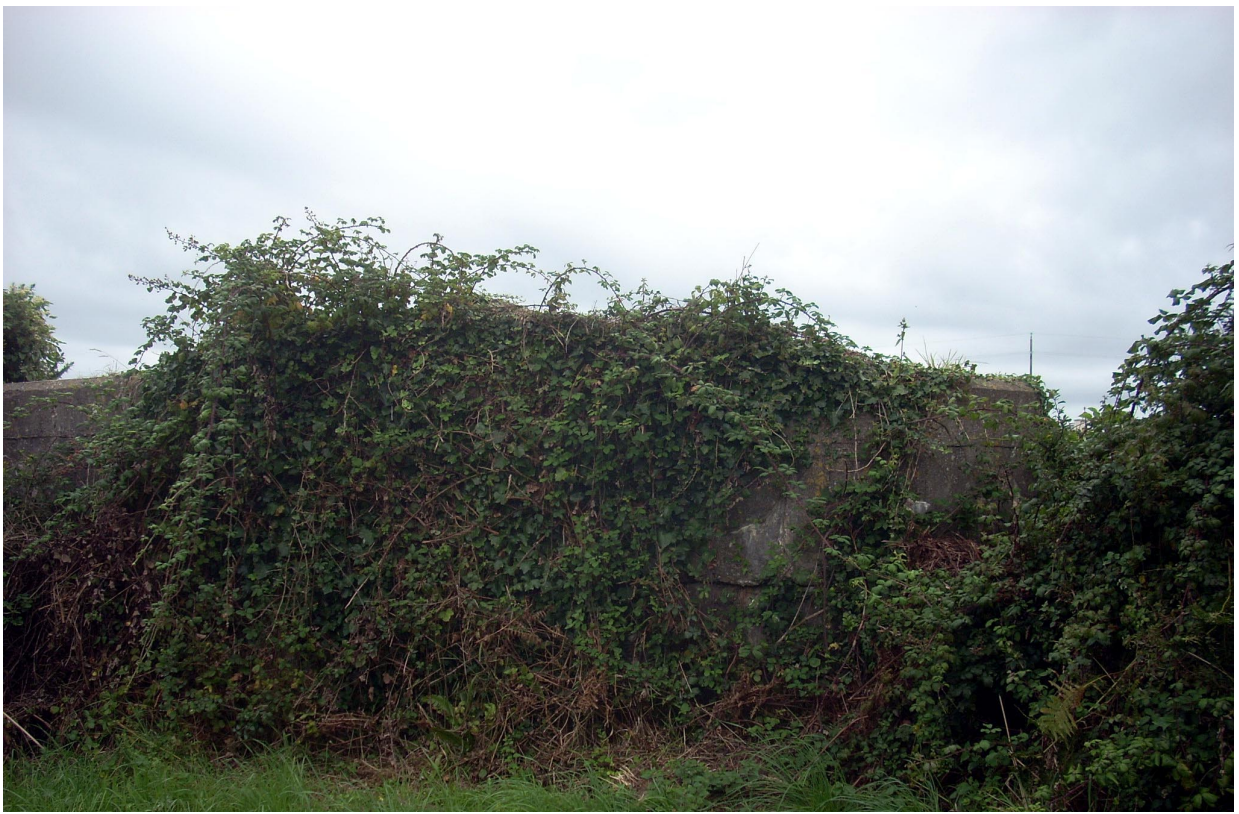

(a)

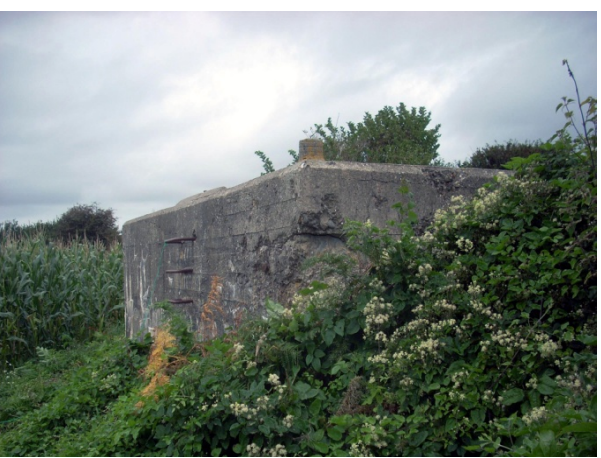

(b)

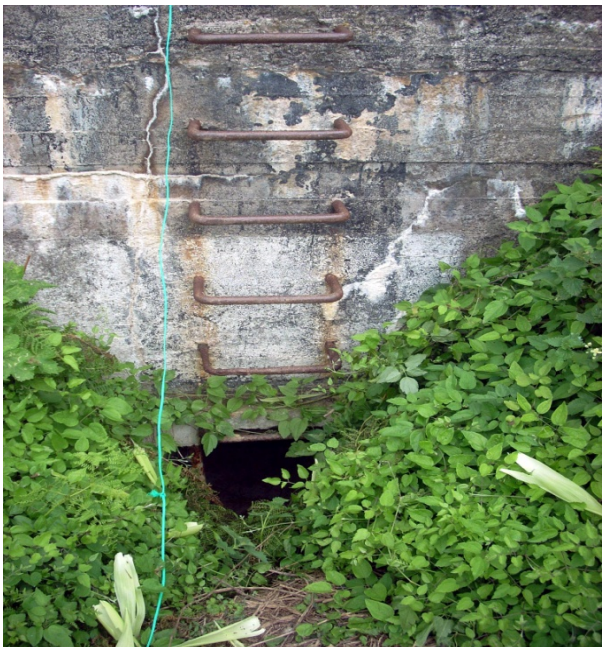

(d)

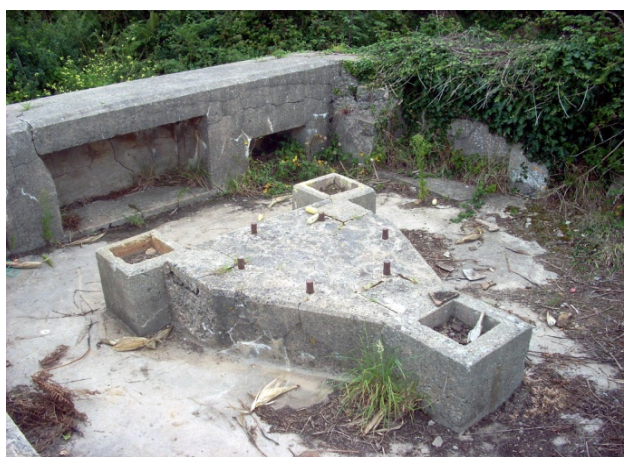

(c)

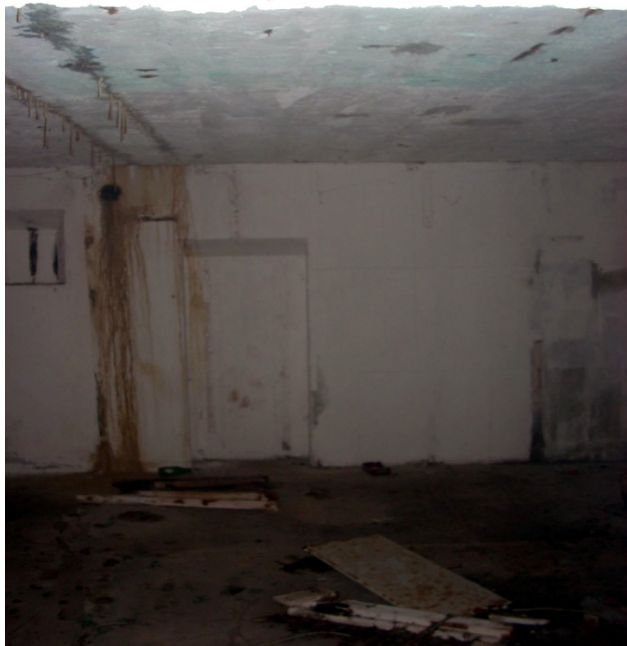

(e)

Figure 4. Keringar Vihan radar base-Vf or SkFlak bunker (9)-(a) bunker concrete structure covered by vegetation; (b) metallic stair above the entrance; (c) Flak gun emplacement, in the middle gun support with square cavities and circularly disposed gun support joints, on the upper side ammunition niches; (d) bunker entrance; (e) bunker interior with probably original white painting. 
However, a bit surprising is the absence of a Würzburg radar for precisely direct the fire of the Flak guns of the base. It is also not clear from where the power supply for the radar/s arrived, i.e. either from the French power network or from German power generators.

\section{FuMG381 Kervingam-Kerdené-Radar Base}

Indicated as FuMG381 Kervingam in the lists of the Deutsche Atlantikwall Archiv (DAWA, 2013) and as Kerdené radar base by the Rapport Pinczon de Sel (Patrimoine Region Bretagne, 2003a) (48 38'20.64"N, $\left.4^{\circ} 11^{\prime} 47.7^{\prime \prime} \mathrm{W}\right)$ (Figures 6-10), this radar base comprised one radar emplacement and one or two observatories. One FuSE80 Freyaradar is identified in service at the base (DAWA, 2013). The site visit took place on 25/09/2016.

The $10 \times 8 \mathrm{~m}$ type 5 stone brick, split wall emplacement for Freya radar (Figure 7) was about $2 \mathrm{~m}$ high and $1 \mathrm{~m}$ thick, and its entrance was protected by a wall about $1 \mathrm{~m}$ high and $1 \mathrm{~m}$ thick. It was built around a preexisting two roomshouse of which only the foundations remained visible. Due to its reduced dimensions $(7 \times 6 \mathrm{~m})$ it is possible that the house hosted agricultural materials, shepherds or small cattle. The purpose of a square wall block about $1.5 \times 1.5 \mathrm{~m}$, between the two rooms remained unknown. The absence of a V229 concrete support confirmed that the emplacement hosted the FuSE80 Freya. The leg support for this radar was located in the space of the house. The preservation state of the bunker structure was good without damages due to combats.

About 10 meters away from the Freya emplacement, a heap of stones marked the presence of an antenna emplacement (Figure 6, Figure 8). It was constituted by a single antenna support and three concrete, cubic blocks for antenna anchoring cables. The antenna support, in its original position, presented a crumbled concrete structure due to the antenna eradication or blasting. The anchoring blocks preserving their original concrete, cubic structure and originally located far from the emplacement, were collected on the support for facilitating field cultivation. The single antenna support and the three anchoring blocks suggested a vertical telecommunication antenna of unknown type and height, which, although close to the emplacement, has not obstructed the northern coastal surveillance sector of the Freya radar.

Isolated in a field of artichokes, about $100 \mathrm{~m}$ far from the Freya emplacement, a heap of stones marked the ruins of a construction (3) (Figure 6, Figure 9). Its much degraded preservation state did not permitted to identify its shape and purpose. It is possible that it was a preexisting small house used by the Germans as observatory for improving the surveillance of the Kerdené coastal sector, dynamited at the retreat of the German troops.

The observatory (Figure 6, Figure 10) was a $10 \times 5 \mathrm{~m}$, two floors construction. The stones used for its lower floor and the bricks used for its upper floor (Figure 10(a)) suggested that a preexisting local, one floor house was elevated by one floor by the Germans and provided with an observation window. The observatory structure was rather degraded: the rear portion was collapsed and covered by the vegetation. The collapse reason, i.e. structural failure, combat damage or blasting, remained unknown.

The search on the terrain for a support $V 229$ for FuSE 65 gave no result, indicating 


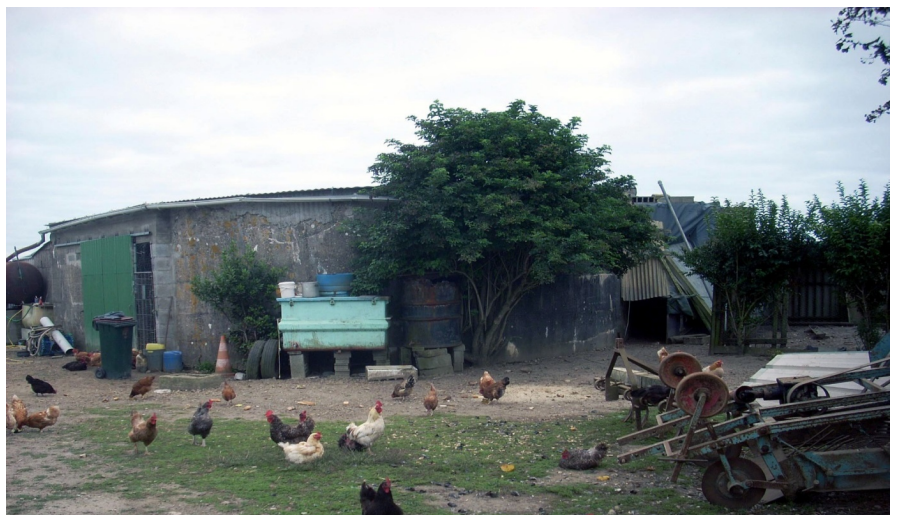

(a)

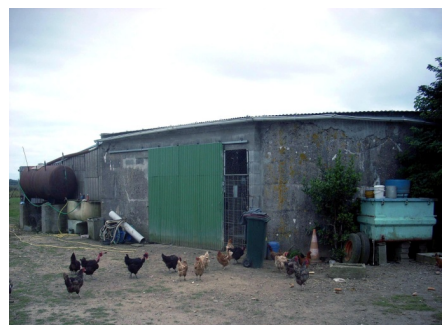

(b)

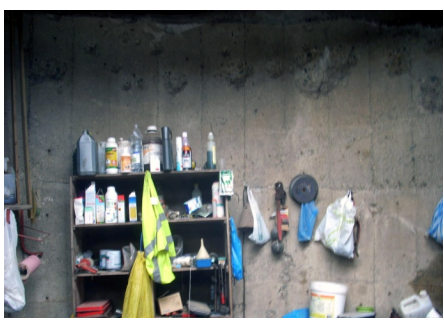

(d)

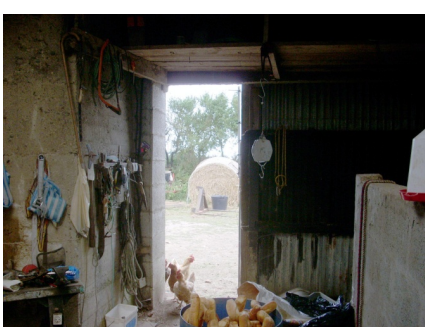

(c)

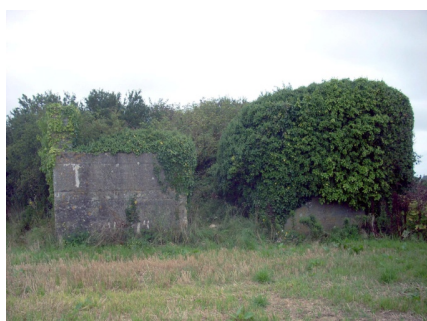

(e)

Figure 5. Keringar Vihan radar base-(a) type 1 concrete, split wall emplacement (8) for Freya radar, main entrance on the left, secondary entrance on the right covered by materials; (b)-(c) details of the main entrance of the type 1 split wall emplacement; (d) internal wall with, on the upper side, impact cavities; (e) type 5 concrete, split wall emplacement (10) for Freya radar.

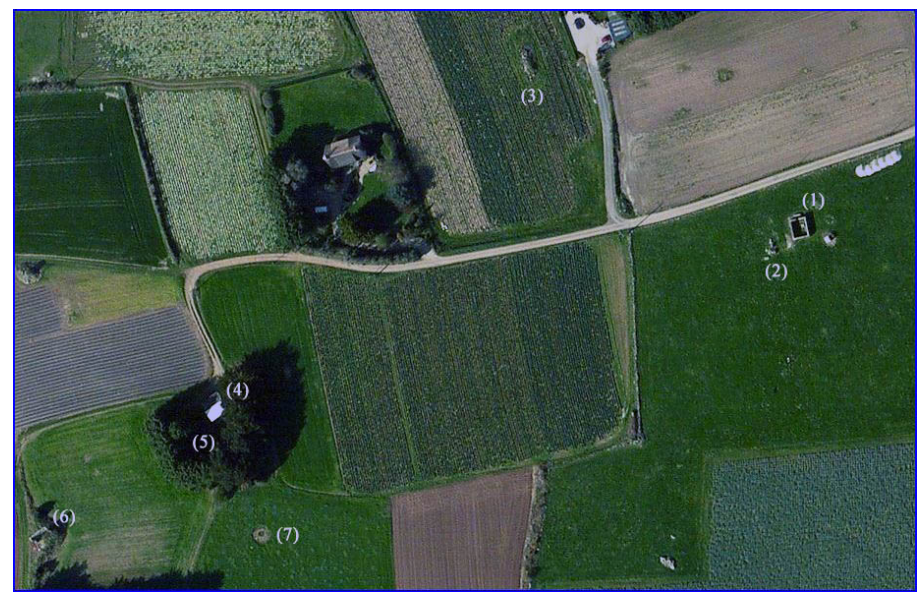

Figure 6. Kervingam/Kerdené radar base-(1) Freya radar emplacement, (2) ruins of an antenna emplacement, (3) ruins of a possible observatory, (4) residence, (5) megalithic stone circle, (6) observatory, (7) possible anti-aircraft gun emplacement [Zoom Earth]. 


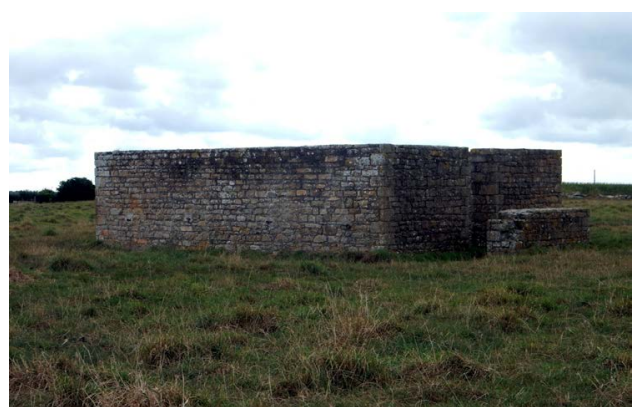

(a)

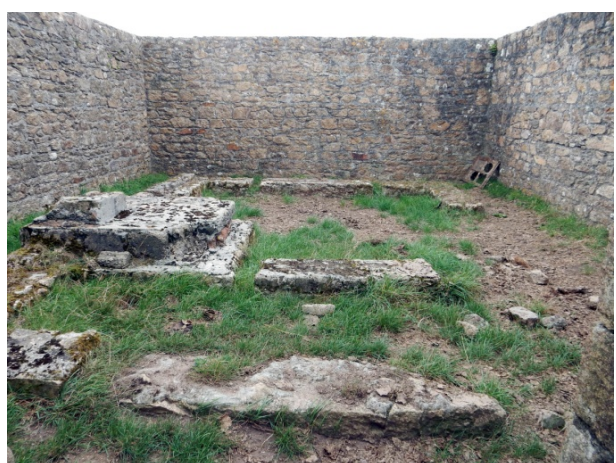

(b)

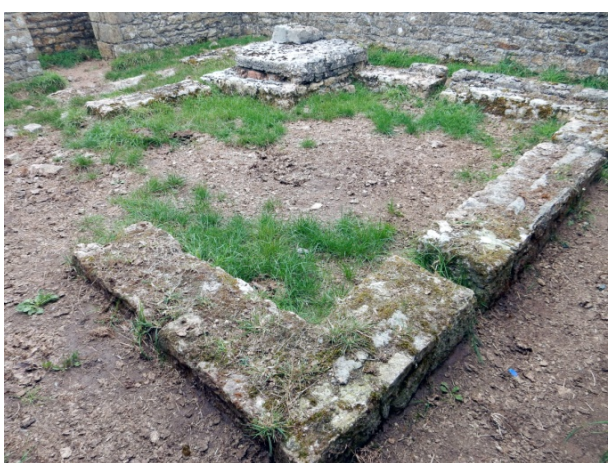

(d)

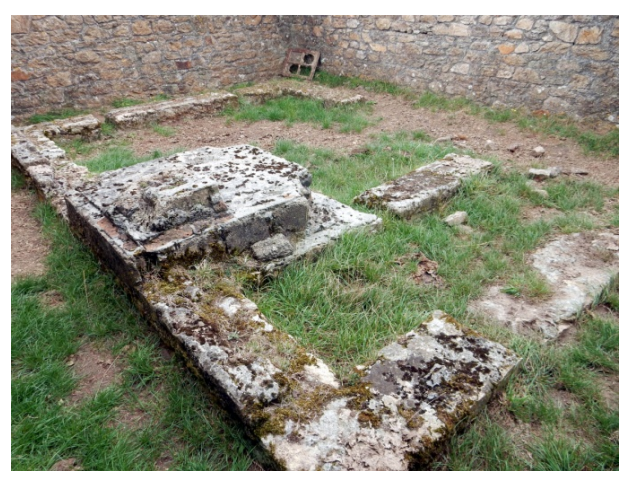

(c)

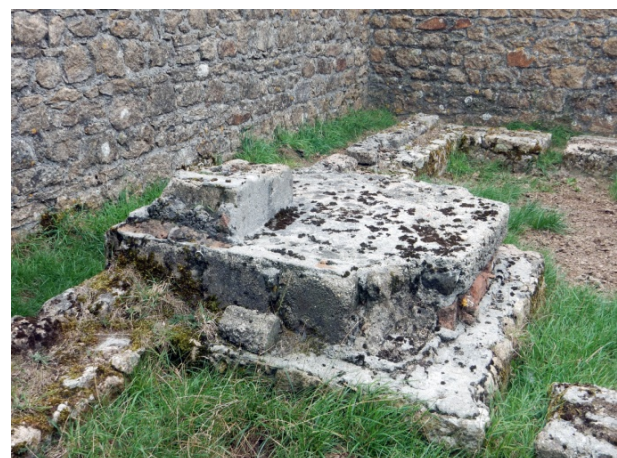

(e)

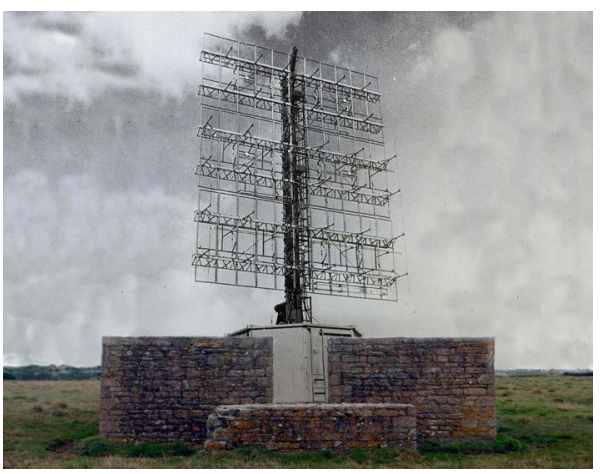

(f)

Figure 7. Kervingam-Kerdené radar base-Freya radar emplacement-(a) type 5 stone brick splitter wall emplacement, on the right entrance protecting wall; (b) inside of the splitter wall with house foundations; (c) two rooms house foundations with square wall block between the rooms; (d) square block and bigger house room; (e) details of the square block; (f) artistic radar emplacement reconstruction, from the top: Emitter, receiver, IFF receiver and instrumentation cabin-Freya radar starting image (von Kroge, 1998). 


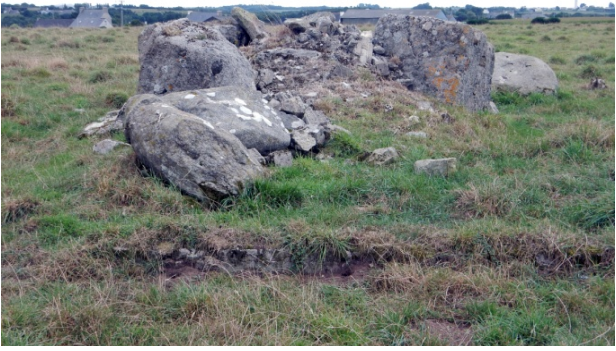

(a)

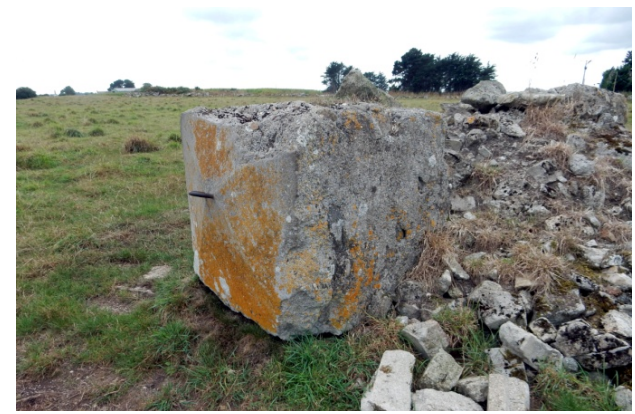

(c)

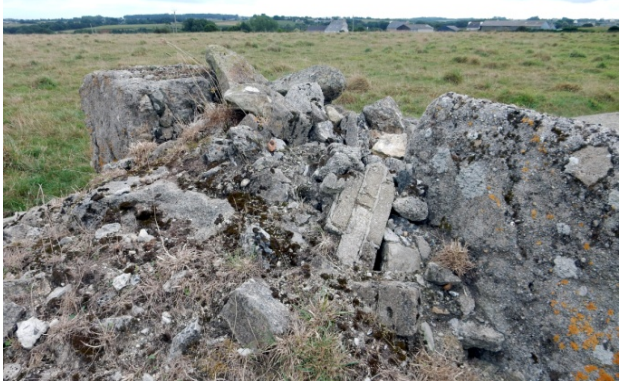

(e)

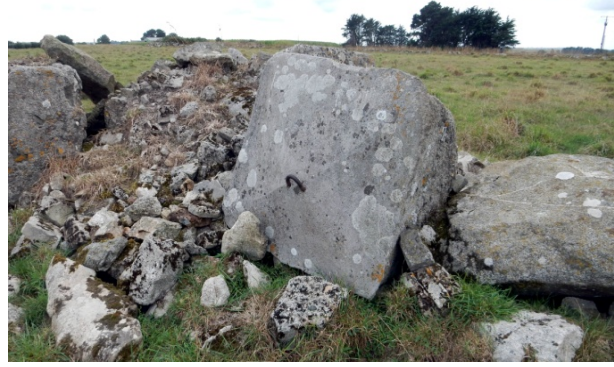

(b)

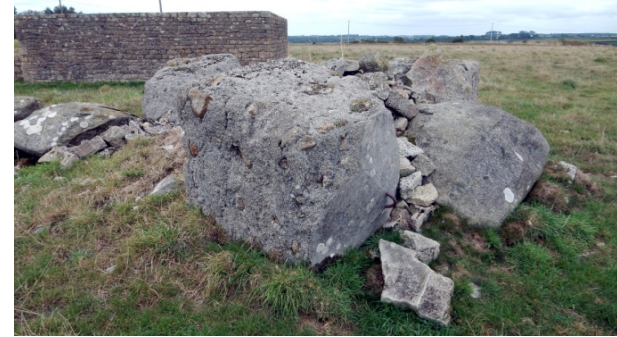

(d)

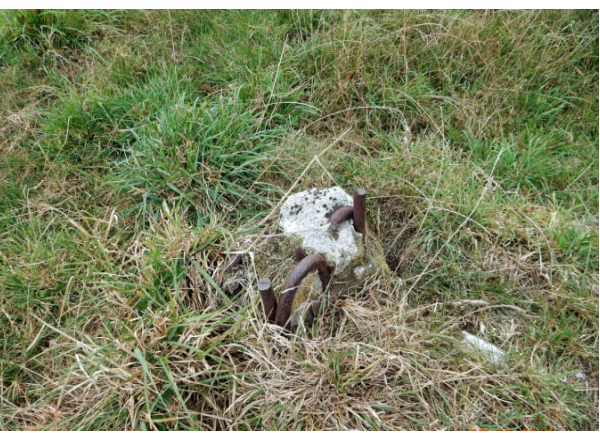

(f)

Figure 8. Kervingam-Kerdené radar base-(a) heap of stones; (b) crumbled support structure and first concrete, cubic anchoring block; (c) second concrete, cubic anchoring block; (d) third concrete, cubic anchoring block; (e) crumbled antenna support; (f) anchoring joint in the terrain.

that probably this base was an early warning radar base. If another Freya or Würzburg radar was present it was mounted on its own support and not provided with a protective split wall emplacement. The search for traces of possible disappeared wooden barracks hosting soldiers' lodgments, a canteen, kitchen and latrines gave no result. A possible estimation to about 30 - 40 personnel members in service at the base is rather uncertain. Nobody was present on the site to whom asking information about the base and the nearby stone circle.

\section{The Kervingam-Kerdené Stone Circle}

It is not infrequent in visiting German military structures in Brittany to discover rests of much more ancient megalithic constructions. In the case of the Kervingam-Kerdené radar base, the visit allowed to discover, close to a residence, a megalithic stone circle or horseshoe stone circle or cromlech $\left(48^{\circ} 38^{\prime} 17.32^{\prime \prime N}, 4^{\circ} 11^{\prime} 49.57^{\prime \prime} \mathrm{W}\right)$ (Figure 11). Certainly 


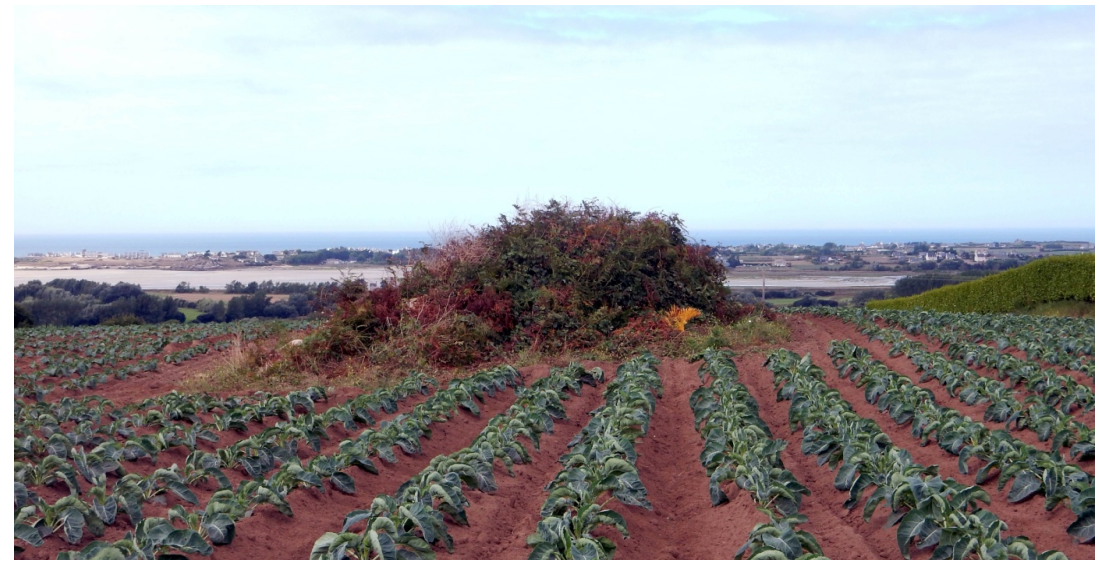

(a)

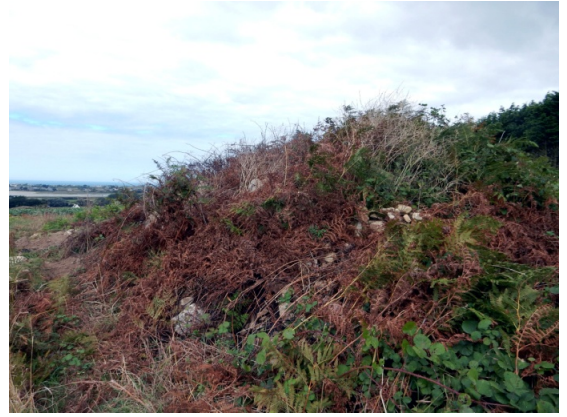

(b)

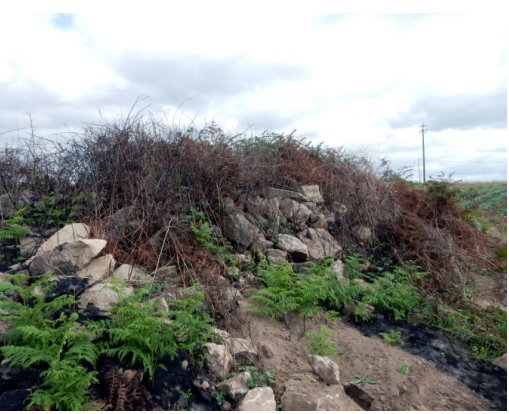

(c)

Figure 9. Kervingam-Kerdené radar base-possible small observatory (3) - (a) ruins in front of the Kerdené coastal sector; (b) ruins, west side; (c) ruins, east side.

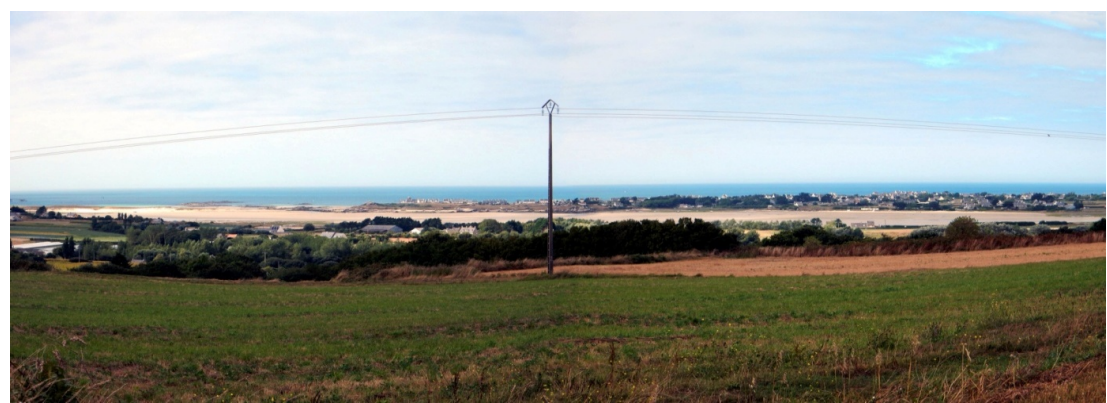

(a)

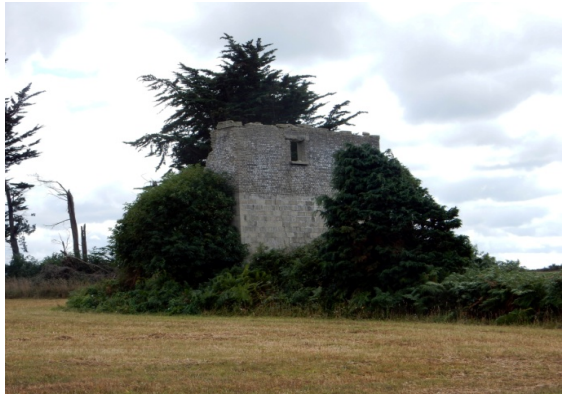

(b)

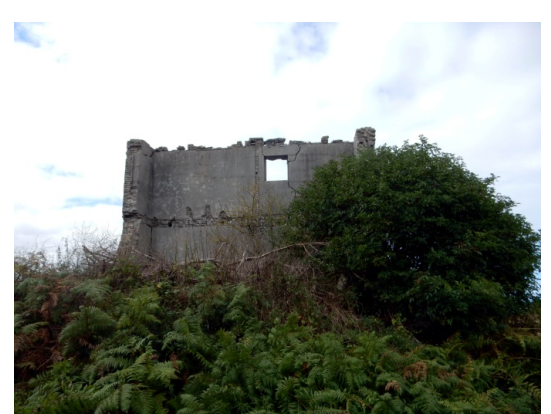

(c)

Figure 10. Kervingam-Kerdené radar base-observatory-(a) surveilled coastal sector; (b) front side with observation window; (c) collapsed rear side covered by the vegetation. 


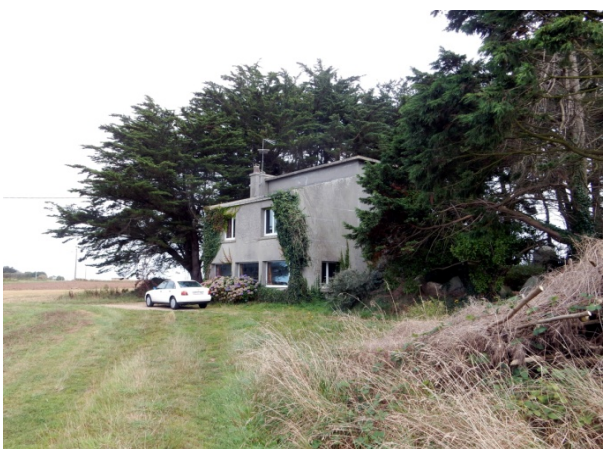

(a)

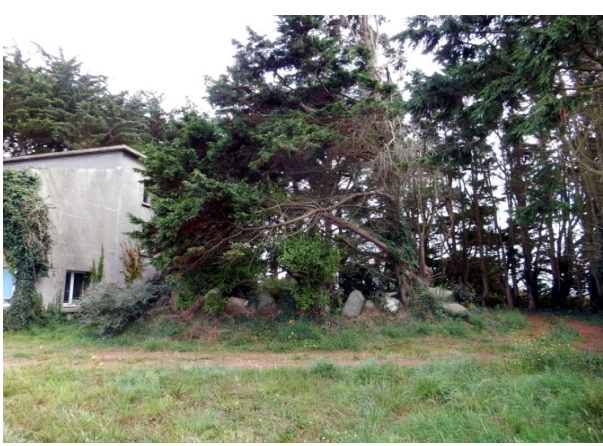

(c)

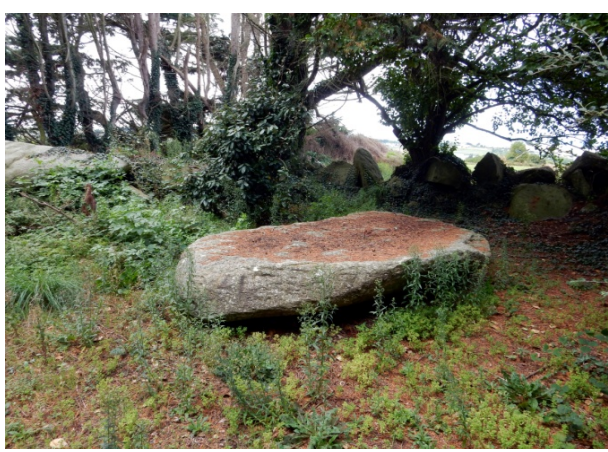

(e)

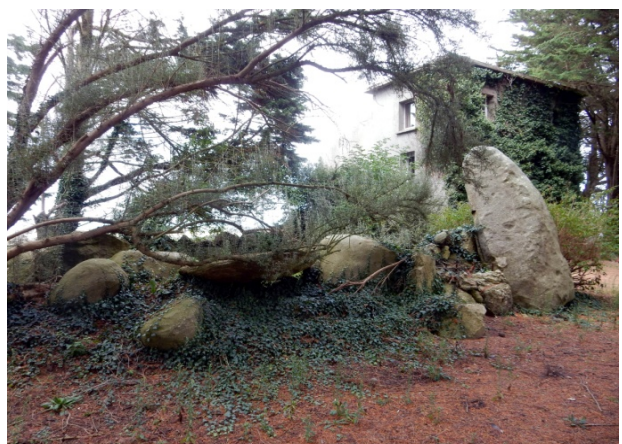

(b)

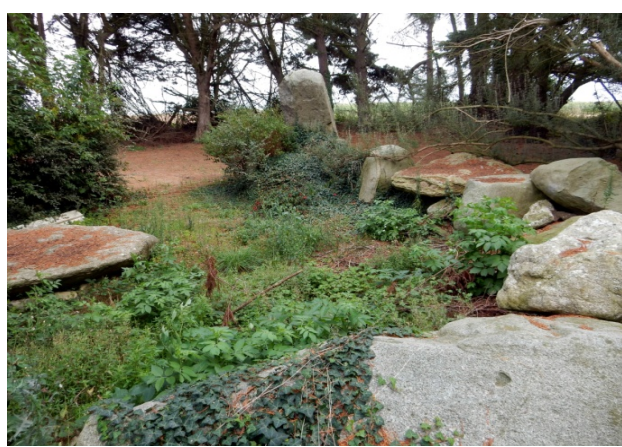

(d)

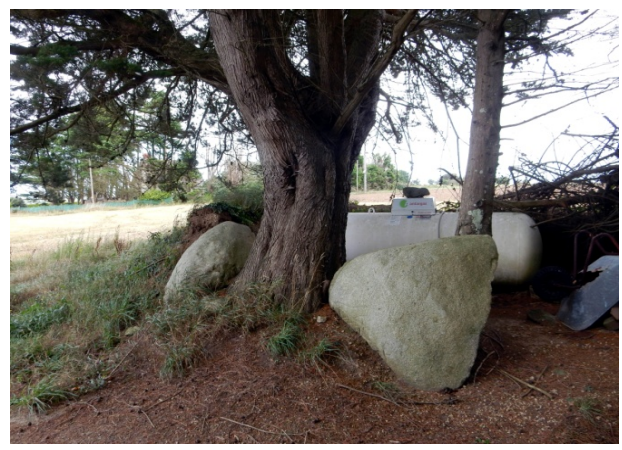

(f)

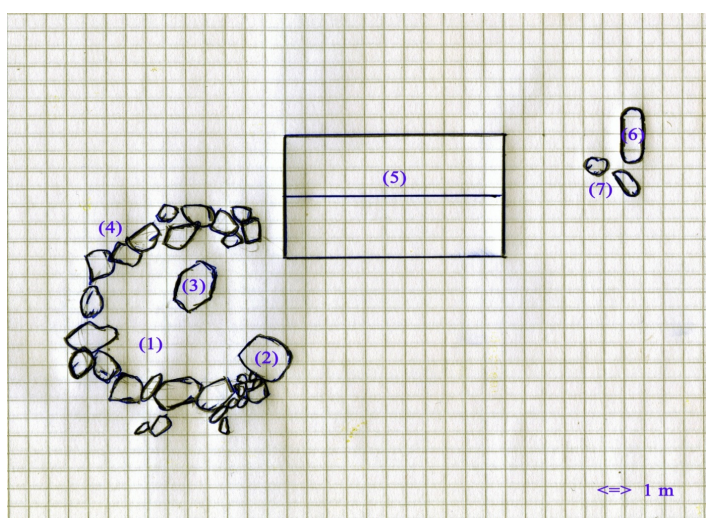

(g)

Figure 11. Kervingam-Kerdené megalithic stone circle-(a) residence; (b) stone circle south side, on the right the menhir, (c) stone circle north side; (d) internal area with the menhir in the middle and the recumbent stone on the left; (e) recumbent stone and internal area north side; (f) stone circle plant: (1) internal area, (2) portal menhir, (3) recumbent stone (4) stone circle, (5) residence, (6) Antargaz cisterna, (7) east stones. 
known by the proprietors and visitors of the residence, nobody was present on the site for confirming its authenticity. Located on the top of the plateau, about $60 \mathrm{~m}$ a.s.l., hosting the radar base, it is not mentioned in the literature considered (Patrimoine Region Bretagne, 2003a; Burl, 1985). It was formed by a stone circle (4) of about $12 \mathrm{~m}$ in diameter, comparable with the diameters of about $20 \mathrm{~m}$ of the similar recumbent stone circles in Scotland and Ireland. The circle was provided with a portal about $4 \mathrm{~m}$ wide, with, as flanker, a $2 \mathrm{~m}$ high menhir (2). The difference between this stone circle and the recumbent stone circles in Scotland and Ireland resides in the recumbent stone (3) of about $3 \times 2 \mathrm{~m}$ located not on the south-west side of the circle, but rather in its internal area. No relief or other decoration was remarked on the recumbent stone and the menhir. The determination of the stone circle age was not possible, but, if authentic, according to the ages of the stone circles in Britain, Ireland and Brittany (Burl, 2000) (Burl, 2010) it could be ascribed to a period comprised between 3300 and 900BC.

The scholars advanced many theories for explaining the purpose of the stone circles: hunter houses, burial sites, meeting places, religious centres, calendars and astronomical observatories (Gibson \& Simpson, 1998). In the case of this stone circle plural purposes have been possible, together or in subsequent order, because of the evolution of the cultures that referred to it. But, the absence of the recumbent stone on the south-west side of the circle ruled out the purpose of lunar ceremonial site, typical of the recumbent stone circles in Scotland and Ireland. The presence of two stones (7) outside the circle, visible throughout the portal, would rather have addressed the attention of one or more observers on the recumbent stone (3) to the East, suggesting the calendar purpose of determining, in a sedentary, agriculture based society, the direction of the spring's Equinox and the starting date for the spring, agriculture works. The absence of further stone landmarks ruled out a possible purpose of astronomical observatory. In any case, excavations appear necessary for establishing the circle authenticity and purpose/s.

\section{FuMG398 Vougo-Kerizoc-Radar Base}

Indicated as FuMG398 Vougo by the Deutsche Atlantikwall Archiv (DAWA, 2013) and as St.P. AV 24 Vougo radar base by the Rapport Pinczon de Sel (Rapport Pinczon du Sel, 1947-1948) (Patrimoine Region Bretagne, 2003b) (48³7'30.34"N, 4²8'5.47"W) (Figure 12), it comprised $1 \times$ Freya radar emplacement, a L406 Abunker and some other small bunkers. One FuSE 65 Würzburg-Riese adapted for the marine surveillance and one Freya FMG40G(gB) Calais are identified in service at the base (DAWA, 2013). The visit took place on 25/09/2016 and deserves to be told for highlighting the role played by a primary witness in investigating this abandoned radar base.

Due to the absence of road indications, two times I failed to reach the site of the radar base. In undertaking the third attempt, I decided to ask information in a farm certainly not far from it. The owner, Mr. L. Gwennec indicated me a rather complicated path for reaching the site, but added that although on the site, a visit could probably unsuccessful because many bunkers are either buried in the terrain or masked by the vegetation. However, he accepted to drive me to the site, adding that in the past the bunkers were on a part of his properties recently sold. Being known by the new pro- 


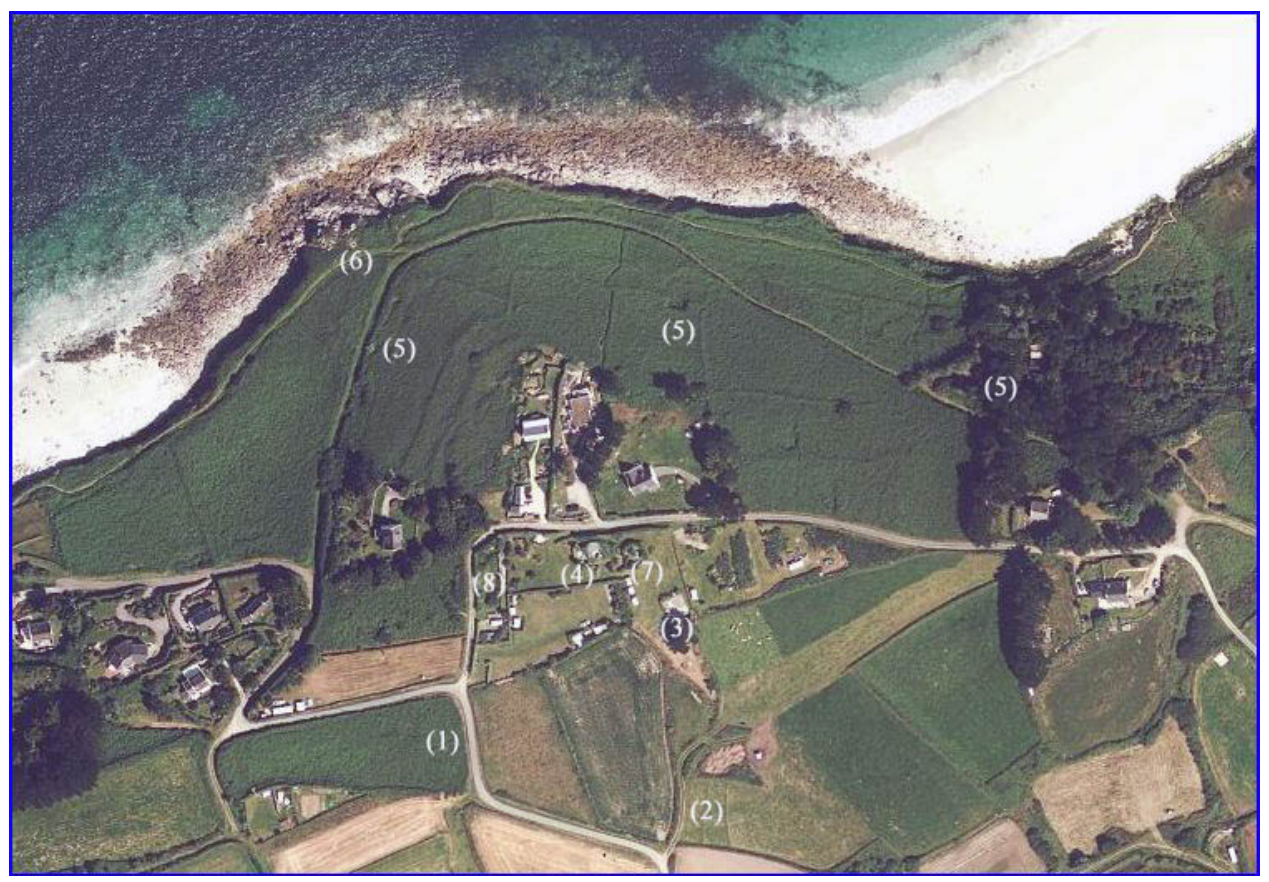

Figure 12. Vougo-Kerizoc St.P. AV 24 radar base-(1) main road, (2) narrow side path, (3) bunker $L 406 A$, (4) splitting wall radar emplacement, (5) bunkers covered by the vegetation, (6) gun emplacement (7) radar emplacement without splitting wall, (8) disappeared wooden barracks.

prietors, there was no necessity of asking permission for visiting the site. According to his indications, after a trip of several kilometres, I directed the car through a narrow side path which separated itself from the main road. He insured that no problem would arrive in travelling on said path, and, in fact, after few minutes of drive, sometimes crawling against the vegetation, we were on the site.

Mr. Gwennec, primary witness, aged of five years at the beginning of the war, asserted that there were never problems with the Germans during the period of the Occupation of France because when they were seen to arrive, all the French were leaving the place. He indicated the position of some disappeared wooden barracks (8) (Figure 12) hosting soldiers' lodgments, a canteen, a kitchen and latrines. Then he advanced up to a bunker type $L 406 A$ (3) (Figure 13), buried in the ground, for permanent machinery like power generators for the radars. The preservation state of the $L 406 A$ concrete structure was good without damages due to combats. On its coverage was the opening of a tobruck and two pyramidal supports for small chimneys or vertical antennas. The interior of the tobruck was empty, without traces of thermal insulation. Materials and terrain obstructed the bunker entrances so that the visit of the interior was not possible. The garage, closed by a modern double door, was inaccessible.

Not far from the $L 406 A$, he indicated a type 1 splitter wall emplacement probably for the Freya FMG40G(gB) Calais (Figure 14). The splitter wall was covered by vegetation therefore the preservation state of its concrete structure remained unknown. The entrance was closed by a modern metallic door and thus not accessible, so that the presence or absence of a $V 229$ for FuSE 65 was not ascertained. He did not remember the square radar antenna of the $F M G 40 G(\mathrm{gB})$ but remembered a rotating circular radar near the splitter wall. The antenna diameter he reported, about $3-4 \mathrm{~m}$, let think that a 


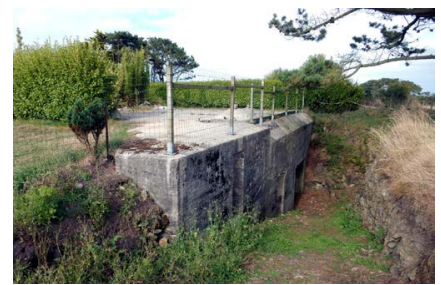

(a)

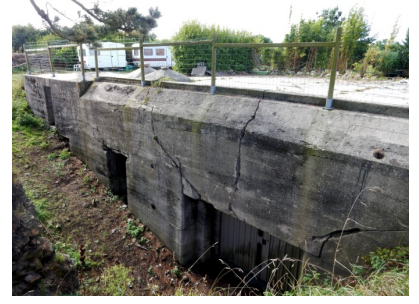

(b)

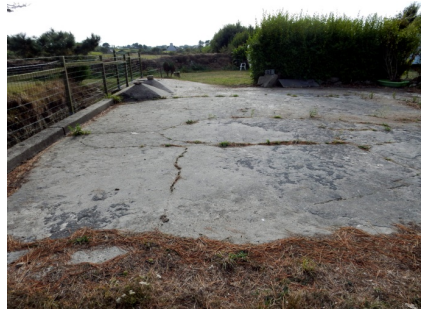

(d)

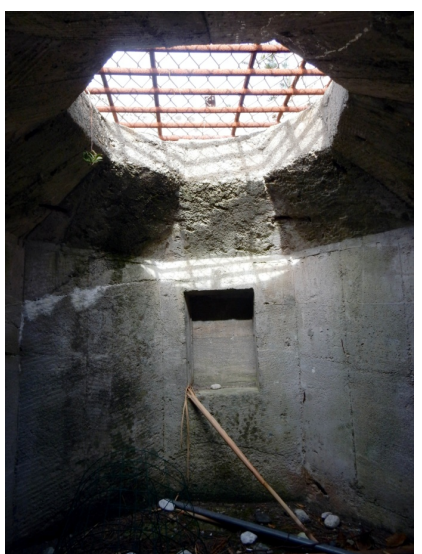

(f)

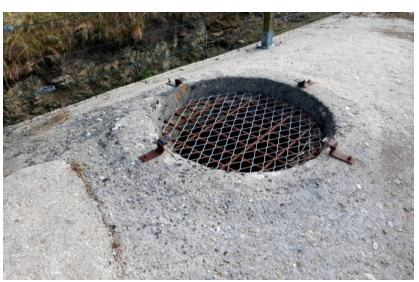

(h)

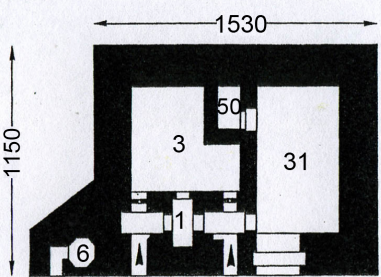

(c)

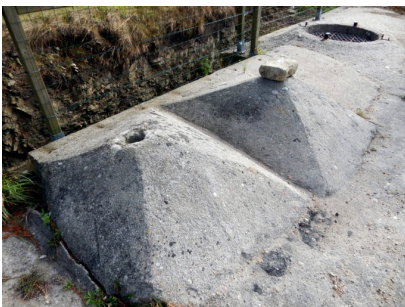

(e)

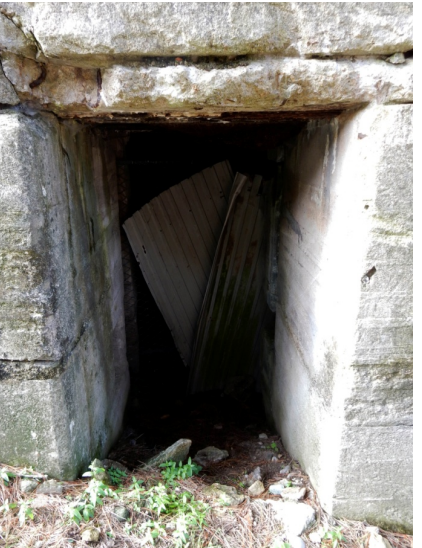

(g)

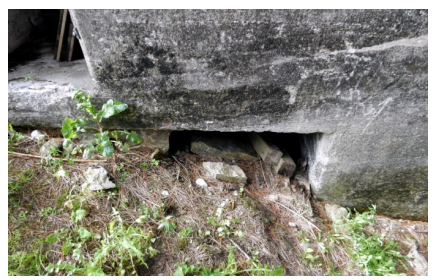

(i)

Figure 13. Vougo-Kerizoc St.P. AV 24 radar base-bunker $L 406 A$-(a)-(b) facade with garage aperture, bunker entrances and tobruck entrance (c) L406 A plant: 1. gas-lock, 3. crew room, 6. observation post-tobruck, 50. fuel depot, 31. garage, (d) (Rudi, 1988); (d) bunker coverage; (e) two pyramidal supports for chimneys or antennas; (f) tobruck interior, octagonal aperture and ammunition niche; (g) bunker entrance obstructed by materials; (h) tobruck, aperture on the coverage; (i) bunker entrance obstructed by the terrain. 


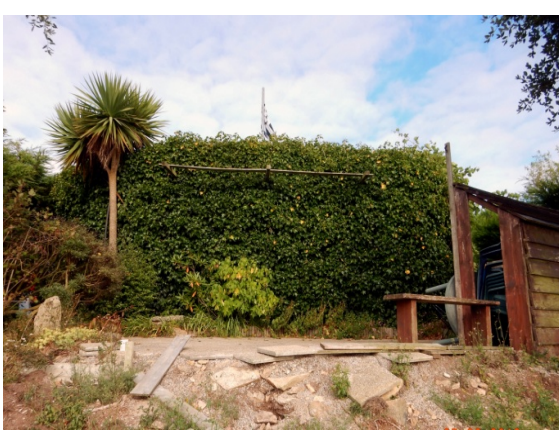

(a)

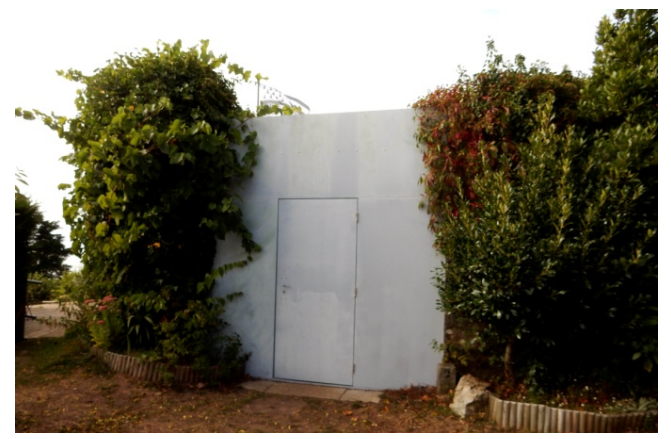

(b)

Figure 14. Vougo-Kerizoc St.P. AV 24 radar base-(a) type 1 splitter wall emplacement; (b) closed entrance of the splitter wall emplacement.

Würzburg radar smaller than a FuSE65, whose circular antenna measured $7.5 \mathrm{~m}$, was present at the base. The search on the terrain for a $V 229$ concrete support for FuSE65 was unsuccessful.

Mr. Gwennec indicated a footpath along the sea coast and declared that some bunker, buried in the terrain or covered by the vegetation, were located along it. He indicated one small bunker rather far from the pathway (Figure 15(b)). Closely surrounded by the vegetation, it was inaccessible and its type remained undetermined. He indicated a hole in the vegetation near the footpath, masking one of the corridor entrances of a bunker type $R 702$ for a group with small gas-lock, provided with a $4 \times 3 \mathrm{~m}$ room (Figures 15(c)-(f)). The room, deprived of all the original furniture, preserved its original white painting. The absence of traces of a chimney and thermal insulation, let think that it was not intended for lodging a group of soldiers, but rather for storing ammunitions and/or materials. He indicated a small bunker (Figure 15(g)) just emerging from the vegetation, presenting a concrete structure severely damaged. $\mathrm{He}$ declared this one and several other bunkers were dynamited during the retreat of the Germans troops. This declaration confirmed the execution by the German343. Inf. Div., responsible of the Finistère, of the order KR Ft 4.8.44, 11:21 (RM 45/IV 464, 1944: p. 202), to evacuate the coasts, destroy all the Marine St.P (Stützpünkte-support points) and dynamite devices and light houses.

Concerning Vougot, the commander of the III. Marine Flak Brigadereceived and probably executed the orders of withdrawing, upon the retreat of the infantry, the Flak batteries located in Vougot, L'Aber-vrac'h and other coastal places to Brest (4.8.44, 11:30) (RM 45/IV 464, 1944: p. 202) and to held the Grèves de Vougot up to the last cartridge (7.8.44, 11:45) (RM 45/IV 464, 1944: p. 221). The Funkmess-Abt., Ozet Bretagne received and probably executed the order KR Ft 3 of 7.8.44 to maintain the FuMO of the Greves de Vougot and others as WN (Wiederstandnest-resistance nest) at said evacuation and wait for reinforcements (RM 45/IV 464, 1944: p. 221).

Mr. Gwennec prosecuted along the footpath up to a small gun bunker. It consisted in a well preserved, non-dynamited concrete structure comprising a circular aperture surrounded by circularly disposed gun support joints on its couverture (Figure 16(a) and Figure 16(b)). Under the couverture, a small entrance gave access to a circular room, partially invaded by the vegetation, hosting ammunition niches (Figures $16(c)-(d)$ ). He 


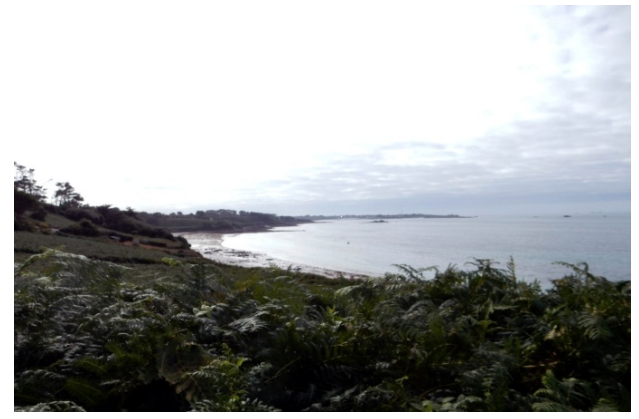

(a)

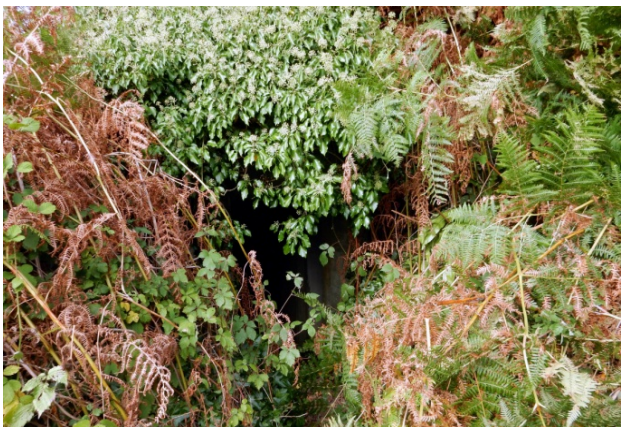

(c)

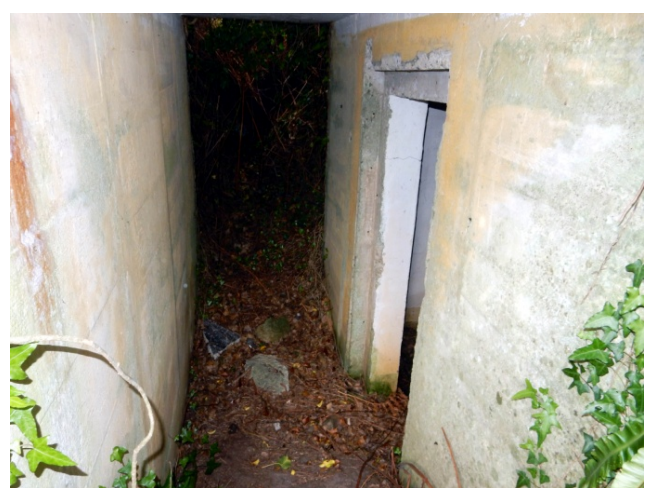

(e)

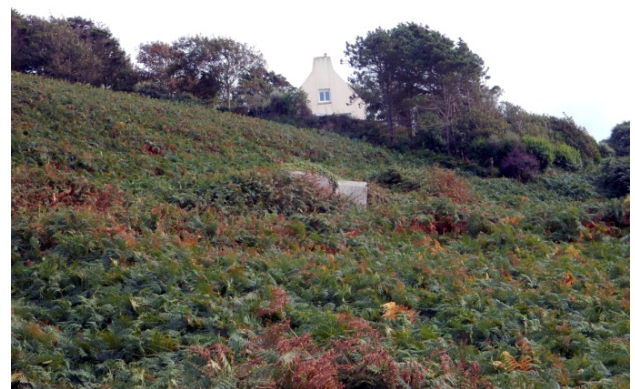

(b)

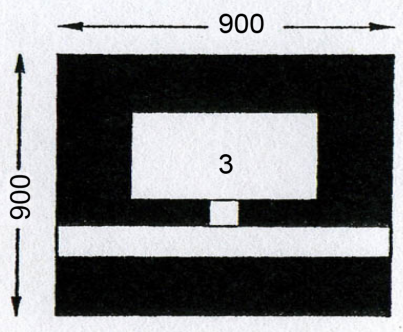

(d)

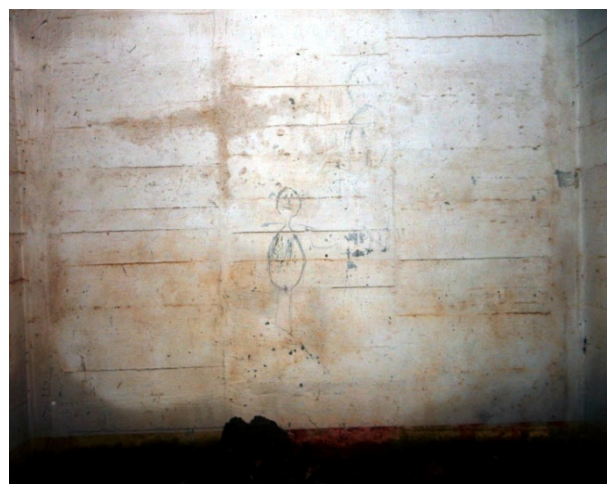

(f)

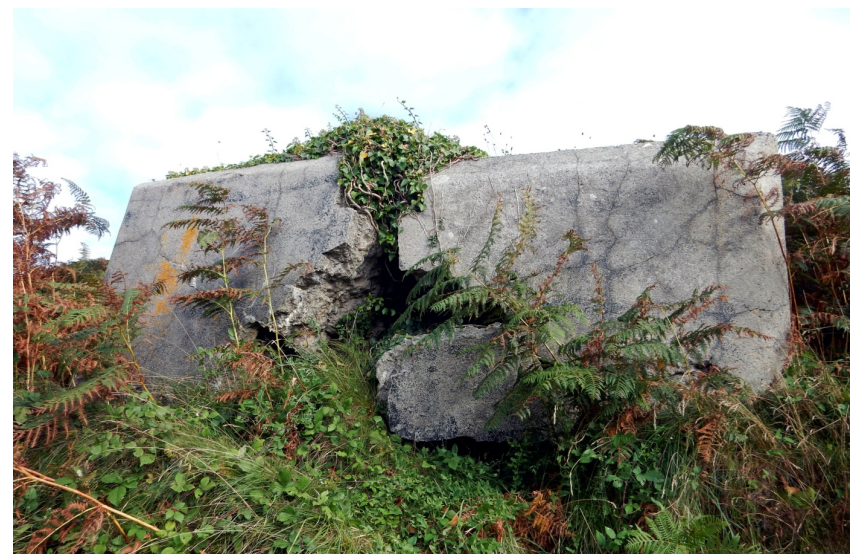

(g)

Figure 15. Vougo-Kerizoc St.P. AV 24 radar base-(a) coastal line; (b) inaccessible bunker encircled by vegetation; (c) hole in the vegetation masking one of the corridor entrances of a bunker type R702; (d) $R 702$ plant: 3. crew room; (e) $R 702$ corridor and room entrance; (f) $R 702$ room preserving its original white painting; (g) dynamited small bunker. 


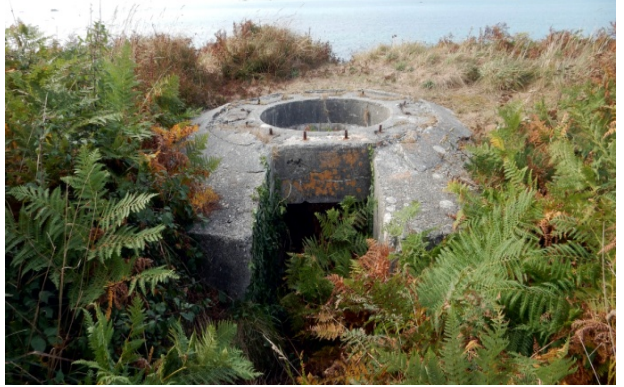

(a)

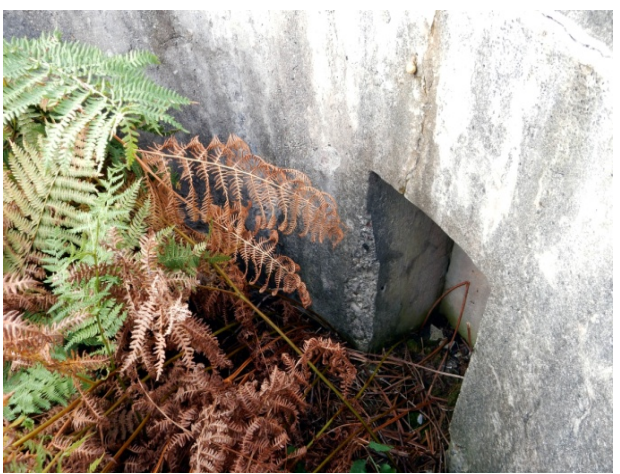

(c)

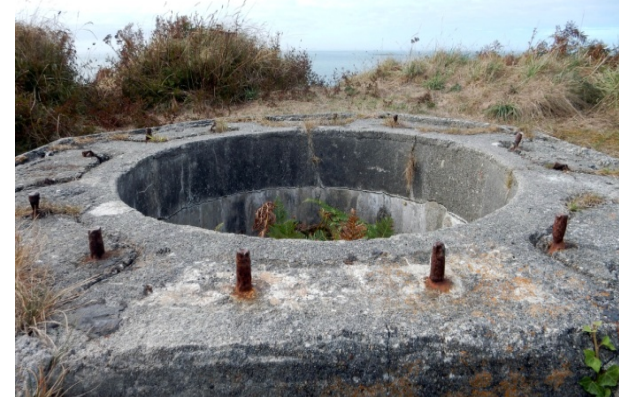

(b)

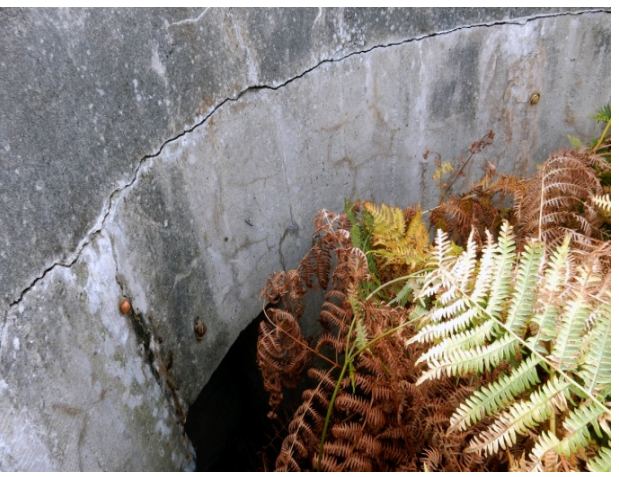

(d)

Figure 16. Vougo-Kerizoc St.P. AV 24 radar base-(a) small gun bunker with circular aperture on the couverture and small entrance to a circular room, in the foreground, barely visible, neighboring reefs (b) circularly disposed gun support joints; (c)-(d) internal circular room with ammunition niches.

was not able to remember relevant details about the gun, but he told that after the war he played with it, and others, more skilled about guns, used it with recovered German ammunitions for playing to bombard some neighboring reefs.

\section{Conclusion}

If the visits on the sites permitted to determine precisely the actual preservation state of the radar bases considered, the memories of the witnesses have enriched this information by identifying non-evident or completely disappeared structures, adding anecdotal and historical information and confirming the recites of archival documents. It is therefore evident that this successful dual procedure should be intensified and extended to all the future studies concerning the Atlantic Wall and, in general, to all the contemporary military structures, as long as surviving primary witnesses will be available.

\section{Acknowledgements}

I wish to thank very much the owner of the site of the Keringar Vihan radar base for his kind permission of visiting the site and his information concerning its radar protective splitting wall emplacements, Mr. L. Gwennec for having ensured a successful visit of the Vougo-Kerizoc radar base site and for his relevant technical and historical information concerning non-evident and disappeared installations and Mr. B. Haas for the re- 
searches in the Bundesarchiv-Militärarchiv (BAMA) in Freiburg.

\section{References}

Burl, A. (1985). Megalithic Brittany. A Guide over 350 Ancient Sites and Monuments. London: Thames and Hudson.

Burl, A. (2000). The Stone Circles of Britain, Ireland and Brittany. New Haven, CT: Yale University Press.

Burl, A. (2010). John Aubrey \& Stone Circles. Britain's First Archaeologist, from Avebury to Stonehenge. Gloucester: Amberley Publishing.

Deutsches Atlantikwall-Archiv (DAWA) (2013). http://www.atlantikwall.info/radar/france/rf_htm\#Bretagne_West

Dupont, P. H., Fresil, Y., \& Tomezzoli, G. (2007). Deutsches Militärbauten bei Rennes, DAWA Nachrichten, Heft 49. Köln: Deutsches Atlantikwall Archiv.

Gibson, A., \& Simpson, D. Eds. (1998). Prehistoric Ritual and Religion: Essay in Honour of Aubrey Burl. Gloucester: Sutton Publishing.

Patrimoine Region Bretagne (2003a).

http://patrimoine.region-bretagne.fr/gertrude-diffusion/dossier/station-radar-encuvement-pos te-d-observation-double/9658661f-2ff7-43d7-82a3-e7cd3a56d93b

Patrimoine Region Bretagne (2003b). http://patrimoine.region-bretagne.fr/gertrude-diffusion/dossier/ensemble-fortifie-station-de-r eperage-radar-av-24/0be03b99-1a34-41b6-aeef-ff4adfbf990c

Rapport Pinczon du Sel (1947-1948). Le Mur de l'Atlantique la Cote de la Manche et de I'Atlantique du Mont Saint-Michel à Laita (Livre IV, Plan_no. 83). Brest: Service Historique de la Marine.

RM 45/IV 464 (1944). Kriegstagebuch des Kommandanten der Verteidigung Bretagne. 1.8.1944-8.8.1944 und 12.8.1944-14.8.1944, Freiburg: Bundesarchiv-Militärarchiv (BAMA).

Rudi, R. (1988). Typologie du Mur de l'Atlantique. Amsterdam: Beetsterzwaag. NUGI 923.

Tomezzoli, G. (2015). The Kieswerk of Pointe Saint-Mathieu and the Atlantic Wall. Advances in Anthropology, 5, 177-182.

Tomezzoli, G. T. (2016). The German Defence System of the Grève de Goulven (Finistere-FR) during the World War II. Archaeological Discovery, 4, 170-199.

Tomezzoli, G., \& Pottier, L. (2007). Die deutschen militärlogistischen Anlagen westlich von Mamers, DAWA Nachrichten, Heft 65. Köln: Deutsches Atlantikwall Archiv.

von Kroge, H. (1998). Gema-Berlin. Geburtsstätte der deutschen aktiven Wasserschall-und Funkortungstechnik. Hamburg: Lühmanndruck. 
Submit or recommend next manuscript to SCIRP and we will provide best service for you:

Accepting pre-submission inquiries through Email, Facebook, LinkedIn, Twitter, etc. A wide selection of journals (inclusive of 9 subjects, more than 200 journals) Providing 24-hour high-quality service

User-friendly online submission system

Fair and swift peer-review system

Efficient typesetting and proofreading procedure

Display of the result of downloads and visits, as well as the number of cited articles Maximum dissemination of your research work

Submit your manuscript at: http://papersubmission.scirp.org/

Or contact ad@scirp.org 